\title{
WILEY

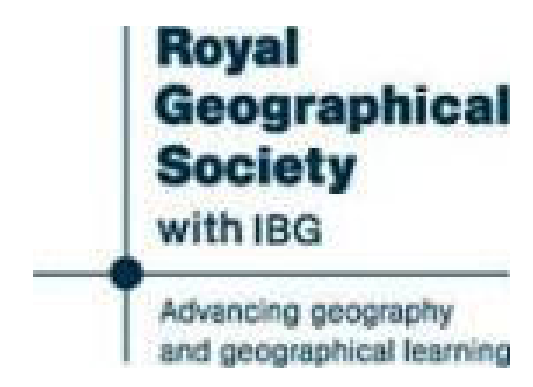

Note on the Ruins in Samarcand, from Fedchenko's Description of the Valley of the Zerafshan, 1869

Author(s): M. Fedchenko

Source: Proceedings of the Royal Geographical Society of London, Vol. 15, No. 5 (1870 - 1871), pp. 393-396

Published by: Wiley on behalf of The Royal Geographical Society (with the Institute of British

Geographers)

Stable URL: http://www.jstor.org/stable/1799276

Accessed: 12/06/2014 17:01

Your use of the JSTOR archive indicates your acceptance of the Terms \& Conditions of Use, available at http://www.jstor.org/page/info/about/policies/terms.jsp

JSTOR is a not-for-profit service that helps scholars, researchers, and students discover, use, and build upon a wide range of content in a trusted digital archive. We use information technology and tools to increase productivity and facilitate new forms of scholarship. For more information about JSTOR, please contact support@jstor.org. 


\section{Note on the Ruins in Samarcand, from FEDCHENko's Description of the Valley of the Zerafshan, 1869. \\ (Communicated by RoBert Micheli.)}

The monuments of Samarcand are all of a religious character; they are either Mesjids or tombs. Their foundations, judging by their remains, were laid by Timur. There are no ruins in the city of a character more ancient than these.

In the centre of the city, separated from each other by a wide plain, stand three Medressés. The one against the western horizon is called Ulugh-Bek, after Timur's nephew, the well-known astronomer, who built it; the one on the east side of the plain is Shir-dar; the third, standing between the two first, is Tilla-kari. The interior arrangement is the same in all three, and is similar to that of large Medressés generally. It consists of a large quadrangular court, surrounded by a range of two-storied buildings, with chambers occupied by teachers and pupils. The Mesjid or house of prayer, is on the side facing towards Mecca. The Mesjid particularly noted for the decorative art lavished upon it is the one in the Tilla-kari; its walls are covered with handsome paintings. The wall of the niche where the Imaum (or the image called Mikhrap, which presents itself to the Moslem mind in prayer) is supposed to be, is gilded over, and bears the inscription: "There is no God but God, and Mahomet is his Prophet."

The Shir-dar Medressé is so called because of the two gigantic figures adorning the front of the building, which M. de Khanikof took for lions. These figures are made of coloured glazed bricks. Time has had considerable effect upon them, yet it has not quite obliterated their character.

The devices in variegated glazed tiles on the outer walls of these edifices lend them a peculiar originality and beauty, adding to the effect of the odd style of architecture. The arches are bold, the minarets gigantic. The inscription on the walls of Shir-dar, which is in verse, and in honour of Jelengtash, the builder, affirms that the Monn placed the finger of astonishment on her lips on beholding these splendid edifices.

These three Medressés were built after Timur's time. The Ulugh-Bek was built in the year of the Prophet 822, or 464 years ago, and the two others were completed in 1028, i.e. A.D. 1612.

Besides these, there are in Samarcand six other buildings of antiquity, dating from Timur's time. 'These are, Shah-Zinda, Bihi-Khanym, GurEmir, Ak-Serai, Ishrat-khana and Bihi-Khanym-Gur-Khana. Of these the best preserved are Gur-Emir, where the great Emir was buried, and ShahZinda.

The Shah-Zinda is outside the town, a little more than a mile from the gates of the same name on the Tashkend road. The gateway opens upon the road; inside this a flight of 37 steps leads up to a long open gallery, flanked by two elevated chambers, capped with cupolas, conducting to the principal Mesjid. Here, behind an iron screen, fastened with a padlock in the shape of a fish-the emblem of silence-is a monument in honour of Shah-Zinda. Lehmann, Khanikof, and Vámbery, have said that the ShahZinda was the summer palace of Timur, whither he used to resort for pleasure and recreation. M. Fedchenko is of a different opinion. He does not believe that the building could have been devoted to pleasure; it was erected in a cemetery, and is even now surrounded by ancient tombs. There are no habitable chambers in the Shah-Zinda; the rooms are either Mesjids or receptacles for the remains of the wives, children, and relatives of Timur. The following legend is related by the Mollahs of the place concerning the raising of the building and the fish-shaped padlock: A thousand years ago 
there dwelt a Saint, whose name was Hazret-i-Shah-Zinda. He one day dug a pit, and disappeared in it, saying he would live there eternally. Time fled, but there were unmistakeable signs of the continued existence of the Saint. Timur, being greatly moved by this extraordinary circumstance, wished to be convinced of the miracular preservation of the holy man, and therefore caused several people to be let down into the pit. But not one of these men returned again to the top, much to Timur's consternation, and to the increase of his curiosity and awe. At last one man volunteered to descend, directing, however, that he should be lowered head foremost, "because," he said, "it is not respectful to go down feet foremost to the Saint." It was, he thought, because all the others had done so that they had not reappeared. When this man reached the bottom of the pit, he found the Saint in prayer, and was so struck by his appearance, that he fainted, remaining senseless for three dars. When he recovered, the Saint said to him, "It is well! Thou art evidently a God-fearing man; but beware lest thou speakest of that that thou hast beheld. If thou utterest a word of what thou hast seen, thou and thy children unto the eighth generation shall surely be dumb." The man was brought back to the earth's surface. On being pressed by Timur for an account of what he had seen, he at first refused to give it; but on being threatened with death he told all ; and it came to pass that the man was. struck dumb. Timur, in the interest of the poor man, for whose sin he was himself answerable, prayed fervently to the Saint, and to propitiate the latter, erected in honour of him the splendid edifice called the Shah-Zinda. Nevertheless, says the legend, that man and his children unto the eighth generation, were all dumb.

The Bihi-Khana Medressé was built in the year 787 by the wife of Timur, a Chinese princess, whose name it bears. It is now in a very dilapidated state; the magnificent arch over what was once the principal entrance, and the immense dome of the Mesjid have almost entirely crumbled away. The stones still continue to give way, and to fall when an earthquake is felt. The people of Samarcand no longer regard it as a holy place, but look upon it simply as a ruin, the court-yard within being given up to keepers of arbas and horses. Bihi-Khanym lies buried in an adjoining octagonal building, called Bihi-Khanym-Gur-Khana.

Timur lies interred in a building called Gur-Emir i.e. the tomb of the Emir. This is a quadrangular structure, surmounted by a large dome. The surrounding arches and the tall minaret have crumbled away, with the exception of one arch and a single minaret. The interior is reached through a dark corridor, where, behind an iron screen, are several tombstones. Under the nearest stone lies Mir-Saïd-Banak, Timur's preceptor and friend. The entire building was raised by 'limur over Saïd's remains in 762, long before his own death. Timur died in Otrar, within 400 miles of Samarcand, but his body, according to his own directions, was laid by the side of that of his preceptor. The stone over Timur's grave is covered with inscriptions; it is a dark green jasper, while all the others are either marble or plain alabaster. By the side of Timur lies his son Mirza-Mahomed-Djanzir. At Timur's feet rests his Vizier and principal adviser, whose name no one in Samarcand is able to tell. After these come Pir-Mohamed, a relation to Timur, and Miran-Shah his son. In the mikhrab, or niche, facing Mecca, rest the remains of Saïd-Mir-Omar, son of Saïd-Mir-Kubal who was also a preceptor of Timur and who is buried in Bokhara.

By the side of Mir-Saïd-Bariak's tomb there is a small one, which is said to contain the ashes of the grandson of the latter Saint. A spiral flight of six steps leads into the crypt, where there are seven tombstones of white limestone, of which seven are disposed in the same order as those above, being nearly all covered with quotations from the Koran, as it is asserted. In the 
eastern wall of this crypt there was once a door, through which the dead were brought in; it is now built up with bricks.

Devotees and pilgrims flock with great reverence to Timur's grave-though not in such great numbers as in former days. At one time there were four entrances into this building-signifying that people flocked from all the four quarters of the world to the tomb of the great Emir. The court was once enclosed within a wall, of which the gaterways alone exist in the present day. Over each of these gateways is the following inscription in Persian characters : "Amolil-Abdulsahif Mohamed-bini Mahmud albenai."

In a long chamber on the right-hand side on entering the Gur-Emir are buried the female members of 'Timur's family, and on the left are the tombs of bis son Mirza-Shah-Rokh and his family.

Close to the Gur-Emir there is a small building called Ak-Serai, now in ruins, and serving as a stable. Tradition says that here lie the three wives of Timur.

Ishrat-Khana is outside the town. To this place, according to tradition, Timur was wont to repair for recreation. It is now a ruin, but one may still perceive that there were small apartments in it in addition to the large central hall on the second floor. The inhabitants of Samarcand relate that Timur's favourite wife Bihi-Khanym, who caused this structure to be raised, intended that it should contain her tomb. But limur, on paying a visit of inspection after the building was completed, was so delighted with it that he kissed his wife. Confused and pleased by this caress, Bihi-Khanym said : "Let this be Ishrat-Khan's house of gaiety and pleasure; a repository for my remains shall be built elsewhere."

There are many other ancient, though less noteworthy edifices, in and around Samarcand, but more particularly a great number of tombs holding the ashes of men held in estimation as Saints. There is an incredible number in Samarcand itself. One gentleman entering into statistical inquiry into this matter summed up as many as two hundred auliés, or shrines commemorative of holy men.

There is, however, one more building deserving of notice: it is not a monument of antiquity, but is, nevertheless, an object of some interest. The late Emir of Bokhara was in the habit of always passing some summer months in Samarcand, living with his harem and suite in a spacious palace now converted into a hospital, which was purposely built for him within the citadel. In one of the courts of this palace, where he held his state audiences, is the famous Kuk-tash (green-stone), which served as his throne. This is a large block of greyish marble. Many people have been astonished to find that its colour is not green, as its name signifies; the fact, however, is that, although $k u k$ does mean green, kuk tash means simply marble.

National monuments of greater antiquity may, perhaps, be found among the ruins popularly called Afraziab in the northern outskirts of the town, which are connected in the minds of the natives of the country with the name of that mythical hero who is supposed to have fought with Alexander of Macedon. The extent of these ruins, or rather of this dreary desert, is immense. It presents a scene of scattered "kurgans," or tumuli, and of heaps of clay - the remains, probably, of former clay buildings. It is asserted by the natives that coins and other valuables are washed out of these heaps by the spring rains, but it does not appear that any curiosities have been picked up by the Russians.

"Kurgans" similar to those of Afraziab occur in various other places around Samarcand. Encircling them are very frequently to be seen traces of a wall and gateway, and in one corner of such a circle there is generally another and a higher heap of débris. These were doubtless strongholds, the type of which is preserved in the present style of Bokharian forts. The citadel of a town is 
usually built upon a natural elevation increased by additional piles of earth, and encircled by an earth mound. The natives say that these "kurgans" are referable to a period when the people of the country lived in constant feud, and when each settlement had necessarily to be fortified. No traces of tombs or of stone buildings are observable on these mounds, therefore archæological researches in this country of clay structures can be pursued, says M. Fedchenko, only under great difficulties. 